\title{
Current Situation of Building Energy Conservation and Green Building Development and its Transformation and Upgrading Countermeasure in Henan Province
}

\author{
Duan Liu ${ }^{1 *}$ \\ ${ }^{1}$ Henan Technical College of Construction, Zhengzhou, Henan, 450064, China
}

\begin{abstract}
In national environment of energy conservation and emission reduction and green building in China, the development of green building has been gradually promoted in Henan Province. During the 13th Five-Year Plan period, the green building had developed for several decades in Henan Province, and the application of its technology is developing from a diversified perspective. From the analysis of the current development status, although the energy efficiency level of green building has increased by $20 \%$ compared with the 12th Five-Year Plan period, green buildings develop in varying degrees in various cities in Henan province. Due to the high cost of green building, the green building policy is not thoroughly implemented in the whole process. It is urgent to improve the current industrial structures in such a state, change the traditional architectural structures, transform and upgrade the construction industry.
\end{abstract}

\section{Introduction}

The construction of ecological civilization in the course of new urbanization is mainly manifested as advancing the development of building energy efficiency and green building, which is also an essential measure to implement the national energy consumption revolution and energy security strategy and a vital aspect to promote air pollution prevention and respond to climate change ${ }^{[1]}$. Furthermore, it is an important starting point for accelerating the transformation and upgrading of the construction industry. As of June 2016, 147 projects were labeled as "Green Building" in Henan Province, with a total construction area of 22.23 million square meters. Among them, 97 were labeled as green design building, accounting for $66 \%$ of the total number of projects ${ }^{[2]}$, and the building area is 14.18 million square meters, accounting for $64 \%$ of the total construction area. Fifty were labeled as green building operations, accounting for $34 \%$ of the total number of projects, and the construction area is 8.05 million square meters, accounting for $36 \%$ of the total construction area ${ }^{[3]}$. These show that Henan Province has made great achievements in the field of green building, but still lags behind Jiangsu, Guangdong, Shandong and other provinces. Therefore, it is necessary to focus on the following aspects. First of all, building energy efficiency should be improved, and the implentation of green building standard should be promoted in different areas. Secondly, to promote the building energy conservation technology, and the standardized and normalized development of its technology, to increase the application of new building materials, technologies, products and processes in building energy conservation. Thirdly, it is necessary to promote the large-scale development of green buildings, formulate relevant standards, norms and evaluation system in the whole process, vigorously develop green building materials, accelerate the renovation of green construction technology, and give impetus to the efficient disposal and reuse of construction waste ${ }^{[4]}$. Fourthly, the supervision and management mechanism should be improved. A whole-life energy saving supervision system covering building design, construction, operation and maintenance should be established, and a standardized energy efficiency data statistics and reporting system should be established to promote the simultaneous rise of green building in quantity and quality.

\section{Current situation of the construction industry and ecological civilization construction in Henan Province}

\subsection{Construction of Sponge City}

In order to improve urban waterlogging in the rainy season, the government of Henan held a press conference on July 5, 2016, to implement the sponge city program, which raised the topic of Sponge City for the first time. Under normal rainfall conditions, $70 \%$ of the rainfall in the construction industry's built-up areas needs to be drained, but only $30 \%$ is practically discharged. However, after sponge city construction, $70 \%$ of the rainfall can be digested in place. Moreover, it is pointed out that the construction of the sponge city will be planned in an

*Corresponding anthor's e-mail: liubc@dimpt.com, journey579@163.com 
all-round way in future development, which will gradually transit from the transformation of the ecological water system to the construction of green space, ranging from roads and squares to communities and units. Eight provincial cities, such as Zhengzhou and Xuchang, are selected as the pilot sponge cities ${ }^{[5]}$.

At the end of the 13th Five-Year Plan, the first batch of pilot sponge cities have been assessed. Taking Hebi City of Henan Province as an example, the test area lies in 29.8 square kilometers, with an average annual precipitation of $623.56 \mathrm{~mm}$. The investment of the project was 3.29 billion yuan, of which the central government invested 1.2 billion yuan ${ }^{[6]}$. The financial department of Henan Province has granted special fiscal subsidies to these pilot sponge cities, giving special fund 200 million yuan every year for three years. It indicates that the sponge city program runs smoothly and effectively improves the rainfall drainage in urban areas.

\subsection{Construction of utility tunnel}

Henan Province witnessed the rapid urbanization, with both the number of urban population and the scale of industries growing dramatically. However, the construction of urban underground infrastructure is lagging. Utility tunnel refers to a public tunnel that built underground in a city for laying cables, communication pipelines, radio and television pipelines, water supply and drainage pipelines, thermal pipelines, gas pipelines and other municipal utility pipelines. Taking the underground utility tunnel project in Zhengzhou Riverside International New City as an example, it is the first utility tunnel project in Henan Province. Located in the central area of Zhengzhou Economic and Technological Development Zone, the project is one of the new districts in Zhengzhou metropolitan area, covering a total area of 10.47 square kilometers ${ }^{[7]}$. As the urban function district of Zhengzhou International Hub Development and Construction Co., Ltd, the Riverside International New City integrates urban construction and ecological civilization construction, where the utility tunnel technology is a specific embodiment of this project. The underground utility tunnel project in Zhengzhou Riverside International New City runs for 5.58 kilometers through Zhongyang No.12 Street, Jingnan No.9 Road, Jingkai No.18 Avenue and Jingnan No.12 Road. With a total investment of about 270 million yuan, the project was invested by China Construction (Zhengzhou) Urban Development and Construction Co., Ltd., designed by China Northwest Architecture Design \& Research Institute Co.Ltd., and built by China Construction Seventh Engineering Division Installation Engineering Co., Ltd. It represents the projects integrating the whole industry chain invested, designed and constructed by CSCEC. In the process of using, the underground utility tunnel project in Zhengzhou Riverside International New City is highly intensive and strongly scientific, planned and designed in a unified manner. Moreover, the project is monitored throughout the whole process to ensure safety, and is managed uniformly and maintained easily.
The construction of a utility tunnel is conducive to transforming the construction method of the city, improving the security level of the city, perfecting facilities and functions of the city, beautifying the construction of cities, and saving space resources. It is helpful to the intensive and efficient development of cities and their transformation and upgrading.

\subsection{Development of green buildings}

In the whole life cycle of the construction, green building means to save resources strongly, put resource conservation in the first place, and protect the environment from the aspects of energy saving, land saving, water saving and building materials saving, so as to minimize the pollution. The aim is to provide human beings with healthy, comfortable, and efficient buildings in the earth. At the same time, it is the best explanation to unify the development of buildings and nature harmoniously.

Taking the development of the construction industry in Henan Province as an example, in order to promote the development of green buildings, starting from January 1 , 2018, awards will be given to projects within the scope of Zhengzhou New East District, the National Zhengzhou Economic and Technological Development Zone, Zhengzhou Airport Economy Zone, Zhengzhou National High \& New Technology Industries Development Zone, Zhongyuan District, Erqi District, Jinshui District, Guancheng Hui District and Huiji District $^{[8]}$. In addition to public welfare buildings invested by the government, projects that obtain two-star green building design logo will be given a reward of 7.5 yuan per square meter (gross floor area). If get three-star green building design logo will give a reward of 12.5 yuan per square meter (gross floor area) ${ }^{[9]}$. The awards are distributed by the municipal financial department of each development zone and the district-level financial department of the city's five districts in a proportion of $50 \%$.

Suppose the project is not designed or constructed in accordance with the regulations of the green building or building energy efficiency. In that case, it is not allowed to participate in the selection of various kinds of high-quality engineering awards, such as the Award for Construction Technology Achievements (Green Building Innovation), Zhengzhou New Technology Demonstration Project Award, Zhengzhou Green Demonstration Project Award, Zhengzhou High-Quality Structure Project (Structural Shangding Cup) and Shangding Cup ${ }^{[10]}$.

In the development process of green building, the technologies adopted are mainly involved in low energy consumption, high efficiency, economy and environmental protection, integration, and optimization. Furthermore, the benefits between man and nature, the present and the future will be shared. The construction approach is a sustainable road for the construction industry. 


\section{Countermeasures for the transformation and upgrading of building energy efficiency and green building}

\subsection{Improving the level of building energy efficiency}

Great efforts should be made to develop green buildings, promote the energy-saving renovation of existing buildings, and promote the use of renewable energy materials in buildings. It is necessary to strongly encourage the delivery of fully decorated buildings and demonstrate buildings with ultra-low energy consumption. For public welfare buildings, affordable housing and public facilities, the green building standard should be prioritized from the aspects of materials and technology. The review of design schemes and construction drawings should be conducted in strict accordance with building energy efficiency requirements.

Steadily improve the energy efficiency of existing buildings. Firstly, we should continue to upgrade existing residential buildings to conserve energy, improve the technical routes for the energy-saving renovation of existing residential buildings in different areas, and actively carry out pilot projects. We should actively explore a comprehensive renovation model that focuses on energy-saving renovation of buildings in old residential areas, retrofit multi-storey buildings with elevators and other facilities suitable for the elderly, and comprehensively improve the environment. Secondly, we should constantly strengthen the management of energy conservation in public buildings, Establish and improve the mechanism of energy consumption information disclosure, strengthen the construction and management of dynamic monitoring platforms for public building energy consumption, and gradually strengthen the construction of city-level platforms ${ }^{[11]}$. Meanwhile, We should guide local governments in formulating quotas for energy consumption in public buildings, and implement quota-based policies to manage key energy-using buildings and to differentiate energy consumption prices, develop key energy-efficient cities for public buildings, and promote the use of contract-based energy management and public-private partnership (PPP) models for market transformation.

\subsection{Publicizing building energy-saving technology}

The R \& D and application of new technologies such as green construction and building energy efficiency should be improved, and enterprises should be encouraged to develop external advanced building energy-saving technologies. In addition, it is necessary to accelerate the establishment of the assessment system for green buildings and energy efficiency of buildings, and the information platform for assessment. Through the development of the overall assessment system for building energy efficiency with building materials, technology, products, processes and other contents, it facilitates the transformation of building energy-saving technologies into standardized and normalized applications.

Further promote the use of renewable energy in buildings. Firstly, expand the scale of renewable energy application in buildings, take more efforts on popularize solar thermal systems in low-rise urban residences, hotels, schools and other public buildings with stable hot water, take the use of solar energy, air thermal energy, geothermal energy and other solutions for the building Heating system. Encourage the application of solar photovoltaic systems in construction projects. Secondly, we should improve the application quality of renewable energy in buildings. Actively utilize franchising, energy trusteeship and other market models to implement professional operation of the project. Accelerate the formulation and revision of technical standards in the design, construction, operation and maintenance stages [12].

\subsection{Advancing the large-scale development of green buildings}

Green building demonstration projects have been built in some areas at the present stage, but they have not been developed on a large scale with great quality. Therefore, regional governments should be encouraged to establish industrial bases for green building materials, formulate standards, specifications and evaluation systems based on green design, construction, operation and other aspects, and issue the guidelines on green building technologies, to ensure the quality of green buildings. In this way, it can guarantee the development of the city and accelerate the large-scale development of green buildings ${ }^{[5]}$.

Comprehensively promote the development of green buildings in both quantity and quality. Firstly, we should implement a plan of double the number of green buildings in all sectors. We should gradually implement green building standards for all new buildings in towns and cities of provincial administrative regions in the eastern region, and mandatory green building standards for new buildings in provincial capitals and key cities in the central region and provincial capitals in the western region. Secondly, we should take action to improve the process of quality of green buildings. The green building standards of civil construction companies would be gradually incorporated into project construction management procedures. Guide all development plots to implement green control indicators, and carry out planning and design of construction projects according to green building standards. Advocate the fine design of green building. Priority should be given the use of green building materials in projects invested by the government. Accelerate the construction of prefab building production and cultivate leading enterprises integrating design, production and construction, actively develop steel structure, modern wooden structure and other building structure systems ${ }^{[13]}$. 


\subsection{Perfecting the supervision and management mechanism}

The relevant government departments should earnestly supervise the energy conservation and the reduction of buildings, actively urge the building owners or users to choose the building methods and materials conducive to the energy conservation and emission reduction of buildings. Moreover, the regulatory system covering the corresponding links of green construction should be improved. In the top-level design, the energy-saving supervision system should be constructed for the whole life of a construction project. In addition, the supervision and inspection of the whole process of energy-saving buildings should be intensified, and a standardized energy efficiency reporting system should be adopted to improve the pertinence and effectiveness of the supervision of energy-saving buildings.

Accelerate efforts to improve standards for building energy efficiency and the quality of enforcement. Firstly, we should accelerate efforts to raise energy efficiency standards for buildings, revise the energy conservation design standards for new urban buildings, accelerate the implementation of higher mandatory energy conservation standards for new residential buildings in cities and towns in cold regions ${ }^{[14]}$. Demonstration of ultra-low energy consumption and near-zero energy consumption buildings would be actively carried out, and common key technologies for planning, design, construction, operation and maintenance will be refined. We should encourage pilot projects to build zero-energy buildings. Secondly, we should strictly control the quality of implementing energy efficiency standards for buildings, improve supervision over energy conservation in the planning, design, construction, completion acceptance and other aspects of new buildings, and strengthen the responsibility of all parties to the energy conservation of main buildings. We should explore the establishment of a construction quality insurance system for energy-efficient building projects with enterprises as the main players and financial and insurance institutions as participants. A special energy conservation demonstration system will be implemented for ultra-high and over-limit public building projects.

\section{Conclusion}

Green development is the basis for promoting harmonious coexistence between human and nature, and realizing the sustainable development of the construction industry. In the field of ecology, green development emphasizes the idea of "unity of human and nature" and the "people-oriented" concept to realize the all-around development of human and nature. In terms of resource utilization, emphasis is put on saving resources, reducing energy consumption, and adopting energy-saving building materials to realize the green and sustainable development of the construction industry. In terms of construction and production, it advocates green construction, green building, and prefabricated building to reduce the generation of construction waste and pollution discharge to realize the harmony between human and ecological environment.

\section{Acknowledgments}

The author gratefully acknowledges the financial supports by Training Program for Young Backbone Teachers in Higher Vocational Schools in Henan Province under the Grant number of 2019GZGG073, as well as the Research Project by Henan Federation of Social Sciences under the project number of SKL-2020-3055.

\section{References}

1. Zhang,X.Q.(2016) Research on the development and application of modern green building energy saving design. Jounal of Housing and Real Estate, 39:10-12.

2. Fan,W.S., Bai,H.(2016) Development Status of Green Building in Henan Province. Jounal of Shaanxi Construction, 107:23-25.

3. Yang,S., Yu,X.(2019) The influence of BIM on the transformation and upgrading in construction industry. Journal of Anhui Polytechnic University, 34:67-73.

4. Anyang Daily (Electronic Edition) [DB/OL]. http://www.ayrbs.com

5. Ouyang,B.W.(2018) Research on the impact of project organization integration on process performance. Journal of Hunan University of Science and Technology, 10:35-37.

6. Fan,W.S.(2019) The current situation of the development of green building in Henan province. Shaanxi Architecture, 75:55-58.

7. Liang,J.(2019) Prospects into the development trend of the construction industry and the transformation and upgrading path of construction enterprises in 2019. China Exploration \& Design, 391:40-42.

8. Cao,W.L.(2018) Research on green Building Development in Small and medium-sized cities under the background of new Urbanization. Jounal of Southeast University, 89:104-106.

9. The final design of Zhengzhou South Railway Station has been unveiled in the shape of "Lotus Crane Square Pot" which could directed by two subway lines[DB/OL]. http://news.kf.cn/20.

10. Li,G., Yan,L.(2015) On the application of energy saving in building design. Jounal of Urban Construction Theory Research, 36:33-35.

11. Wu,Y.(2013) On the application of energy saving in building design. Jounal of Building\&Material \&Decoration, 12:26-27.

12. Yuan, H.(2012) The problems and countermeasures of building energy conservation in the new era. Jounal of Science and Technology Information, 26:46-47.

13. Wei,X.(2019) Research on the development of building energy efficiency. Jounal of Optimization of 
Infrastructure Management, 31:13-16.

14. Chen,C.(2019) Concept and policy of building energy efficiency. Jounal of HVAC, 32:40-43. 